\title{
DiSCOURSE MARKERS OF HUMOR ANALYSIS IN TREVOR NOAH'S STAND-UP COMEDY
}

\author{
Eko Suci Priyono, Zainur Rofiq \\ Universitas Islam Negeri Maulana Malik Ibrahim Malang \\ ekosucipriyono@gmail.com, zainurrofiq@uin-malang.ac.id
}

\begin{abstract}
Discourse markers have been widely studied in various discourses such as political discourse, legal, media discourse, and even daily conversation. However, there is still a lack of discourse markers research in humor studies. This study was projected to identify the linguistic aspects of humor genre utterances in stand-up comedy performed by Trevor Noah as one of the most influential stand-up comedians. In addition, those linguistic aspect is discourse markers. The data were taken from Trevor Noah's Video entitled Prince Harry \& Meghan Markle's Royal Wedding Live at the O2 London. Afterward, the data were analyzed by using the theoretical framework of discourse marker and its pragmatic functions introduced by Brinton (1996). This study reveals that there are several types of discourse markers used in stand-up comedy, such as ah, and, like, oh, alright, then, huh, well, yes/no, and I know/knew. In addition, all of those discourse markers have different functions, and sometimes one discourse marker serves more than one pragmatic functions.
\end{abstract}

Keywords: Discourse Markers, Pragmatic Functions, Humor, Stand-up Comedy

\section{INTRODUCTION}

A discourse marker is a required element that cannot be separated from our daily live communication. A researcher exposed that discourse markers are an essential part of achieving socialcommunicative goals both in written and spoken discourse (Piurko, 2015, p.5). Some examples of discourse markers that are frequently used in discourse are yeah, well, so, etc. Norrick (2000) has stated that discourse markers can be used to start a discourse, to tag a topic shift, or to quibble for a while to think before continuing (p. 49).

Meanwhile, Brinton (1996) has her definition of discourse markers which is pragmatic markers as it serves pragmatic meaning in the discourse. Brinton explains that discourse markers not only serve in the function of discourse marker as discourse element in the discourse organization but also serve a pragmatic function and term pragmatic markers covers the range of the item functions rather than discourse markers alone. Moreover, Brinton (1996) divided the role of discourse markers (pragmatic markers) into a textual and interpersonal level (p. 38). An interpersonal function of a discourse marker is affected by its textual function. A discourse marker cannot in any way be separated from analyzing its textual function. It is because the fundamental meaning of discourse markers will determine the use of discourse markers in utterance or discourse.

Humor discourse is a linguistic phenomenon that often either intentionally or unintentionally occurs in our daily communication. As a kind of humor, stand-up comedy is rich in linguistic features. Schwarz (2010, p. 3) describes in brief words as 'a combination of various linguistic features of joke telling such as wordplay and punning, hyperbole, repetitions, timing, and paralinguistic choices, which makes it receive great interest from linguists. Many studies have paid attention to this topic through diverse perspectives, such as pragmatics (Attardo, 2008; Attardo \& Raskin, 2017), semantics (Allen, 1988), and cognitive linguistics (Brône \& Veale, 2015). Therefore, my research will deal with the analysis of stand-up comedy by narrowing the scope of investigation into discourse markers of verbal humor expressed in stand-up comedy and their functions. Furthermore, humor as a linguistics phenomenon in stand-up comedy has been studied not comprehensively, which is proven by the small amount of research in terms of this research. One of the studies in terms of the topic mentioned before has been done by Schwarz (2010) who analyzes the aspects of linguistics in verbal humor especially stand-up comedy in her research. She explains that there are many linguistics aspects in verbal humor on stand-up comedy including one of them is discourse marker. Yuniar (2013) also investigates the function of the discourse marker $Y a$ in Indonesian stand-up comedy.

The novelty of this research is that it seeks to investigate the discourse markers' textual and interpersonal functions in English stand-up comedy, as one of the humor genres. The research data were taken from Trevor Noah's stand-up comedy, who is a very famous stand-up comedian. He always puts the hottest world issues upon his jokes. Time Magazine has also declared Trevor Noah as one of the 100 most influential people of 2018 because of his comedy. He also becomes the most popular TV personality of 2018 according to a survey by MVPindex based on data from Facebook, Instagram, 
Twitter, YouTube, and Google Plus reported in hollywoodreporter.com. Therefore, those reasons above may guarantee the sense of humor he produces in his stand-up comedy. Moreover, the data of this research was a video entitled Prince Harry \& Meghan Markle's Royal Wedding Live at the $\mathrm{O} 2$ London by Trevor Noah from Trevor Noah channel, Youtube. It was the performance of stand-up comedian (comic), Trevor Noah in the program Saturday Night Show at the 02 London which received million s of viewers and positive reviews than the other Trevor Noah's video.

So far, there has been no previous research that focused on the discourse marker used in English stand-up comedy comprehensively and under the perspective developed by Brinton (1996). Since this study deals mainly with the pragmatic functions of the discourse markers used in Stand-Up comedy, so Brinton's perspective of discourse markers and its pragmatic function; textual and interpersonal function (1996) is the most suitable framework of discourse marker and its pragmatic function.

\section{MATERIALS AND METHODS}

This research employed descriptive qualitative research. The researcher becomes the main instrument. The data of this present study were collected through several steps. First of all, a video entitled Prince Harry \& Meghan Markle's Royal Wedding Live at the O2 London by Trevor Noah was selected. Then, the researcher watched the video, and then the spoken material of the stand-up comedy performance by Trevor Noah was transcribed in detail by marking utterances with humor-related annotation.

Furthermore, the researcher identified the discourse markers used in Trevor Noah's video by using a skimming reading technique as it centers on pointing out specific information from the content as stated by Rosidi (2008). Lastly, the researcher selected the DMs followed by laughter as the data. Moreover, in analyzing the selected data, the researcher identified the discourse markers used in a stand up comedy based on Brinton's DMs inventory item (1996).

After that, by following the concept of the function of discourse marker by Brinton (1996), the researcher determined the pragmatic functions which consist of textual and interpersonal functions of discourse markers. Lastly, based on the forms and functions found in finding and discussion the researcher concluded how DMs can help to generate laughter in stand-up comedy performance.

There have been some scholars focusing their investigation on discourse markers, such as Schiffrin (1987) and Hyland (2013), who emphasize that discourse markers are following dependent elements which bracket units of talk. They also categorize discourse markers into four kinds which are particles (oh, well), conjunctions (and, but, or, so, because), time deictics (now, then), and lexicalized clauses (y`know, I mean). Fraser (1999) has a dissimilar belief with Schiffrin (1987) about discourse markers. He solely notes discourse markers as a linguistic expression. He points out that discourse marker has two characteristics: (a) It has a core meaning which can be enriched by the context; (b) It signals the relationship that the speaker intends between the utterance the DM introduces and the previous utterance (see also Fraser, 1999; Aijmer, 2002; Muller, 2005)

\section{RESULTS AND DISCUSSION}

After checking the discourse markers used in Trevor Noah's stand-up comedy especially in the humor utterances utilizing the guidance of Brinton's discourse markers inventory item, the researcher found eleven types of discourse markers that match with the list of Brinton's discourse markers inventory item. DMs that appear in stand-up comedy are DMs ah, and, like, oh, alright, then, huh, well, yes/no, and I know/knew.

The first discourse marker that is listed in Brinton's DMs inventory is $a h$. The researcher found several discourse markers $a h$ in Trevor Noah's stand-up comedy as seen in excerpts 6 and 7. We have ascertained that $a h$ appeared in the data functioning as a DM instead of a disfluency filler because, according to Corley \& Stewart (2008, p. 591), it is no more likely to use fillers such as $u h(a h)$, in the fast conditions, as displayed in Trevor Noah's stand-up comedy. In addition, the second discourse marker found is and. It can be observed in excerpt 2. Moreover, one of the most frequently used discourse markers in Trevor Noah's stand-up comedy is like. It appears several times in the humorrelated utterances, and it can be seen in excerpt 4 . The next discourse marker is right/all right. This kind of discourse marker only appears once in the humor-related utterances on Trevor Noah's stand-up comedy. It can be seen in excerpt 5. Moreover, the discourse marker then is also found once in the data on excerpt 3. 
However, the rest of the discourse markers listed in Brinton's DMs inventory, such as actually, after all, almost, anyway, basically, because, but, go, I mean/think, mind you, moreover, just, if, ok, or, really, so, say, sort/kind of, therefore, and you see are, unfortunately, not found in humor related utterances on Trevor Noah's stand-up comedy.

Furthermore, the discourse markers found in this study will be presented in the table below. Moreover, the frequency of the appearance is also added to see which discourse markers are used frequently in the humor-related utterances on Trevor Noah's stand-up comedy.

\begin{tabular}{l|l|l|l|l|l}
\hline DM & Occ & DM & Occ & DM & Occ \\
\hline ah & 7 & 5. right/all right & 1 & 9. yes/no & 8 \\
and & 9 & 6. then & 1 & 10.you/I know & 4 \\
like & 11 & 7. uh-huh/mhm & 3 & 11. Yeah & 3 \\
oh & 2 & 8. well & 1 & & \\
\hline
\end{tabular}

\section{Figure 1. Discourse Markers and Their FrequencyDistribution}

In addition, based on the characteristics of discourse markers proposed by Brinton (1996) along with Jucker \& Ziv (1998) such as Discourse markers usually short and lack phonologically and Discourse markers appear outside the syntactic structure, they usually have no clear grammatical function, there is an addition of one discourse marker which has not been listed in Brinton's DMs inventory item namely yeah in the finding. All in all, there are eleven in the total of discourse marker types used in humor genre utterances on Trevor Noah's stand-up comedy. Moreover, from the discourse markers found in the data, there are several pragmatic functions that will be specifically discussed in the following section.

\subsection{Discourse MARKER AS TOPIC SWITCHERS}

The pragmatic function of discourse markers as topic switchers lies under the layer of textual function. Halliday (1994) stated that textual function is formed in the theme structure of the discourse, the given or new information, and cohesive relations. The cohesive relations which compare to discourse markers are conjunctive relations that relate content components together. In other words, it refers to the organization or the discourse. Castro (2009) elaborates the understanding of opening markers devised by Brinton which says that the pragmatic function of discourse marker as topic switchers is used to present a new topic from a previous topic. It also serves as topic switchers in the partial shift on the topic. Therefore, to move from one topic to another topic or shift in the topic the speaker will use this kind of discourse markers.

Furthermore, there is a discourse marker occurs in the data which serves the the textual function as a topic switcher. It can be seen from excerpt 1 below.

Exceprt 1

Trevor Noah : MEET TREVOR'S UNCLE BOBBY. I DIDN'T EVEN KNOW I HAD AN UNCLE BOBBY!! Well now you do and he shits his pants!!

Audience : Burst of Laughter

The discourse marker well in the excerpt above is used to initiate a topic shift from the topic which discuss the condition of Trevor doesn't have uncle namely Bobby into the new topic that tells Trevor recognizes his uncle starting from the moment of speaking, so in the second topic, he got an uncle namely Bobby. Thus, the discourse marker well in Trevor Noah's stand-up comedy serves a textual function as topic shifters.

\subsection{Discourse MARKER AS NEW INFORMATION INDICATORS}

The next pragmatic function of discourse marker found in the data is discourse marker as new or old information indicators. This discourse marker is used when the speaker wanted to add new or old information so that the flow of the information will be as expected and more understandable. Furthermore, in the data, the researcher found a discourse marker that functions as a new information indicator and it appears several times. The discourse marker which functions as a new information indicator is discourse marker and as illustrated in the excerpt 2 below.

Excerpt 2 
Trevor Noah : Everyone was stressed out about it, Megan Markle's family was in the tabloids. The Daily Mail trying to destroy their lives! Man, when the Daily Mailcomes after you, they do not mess around! They will find that one Uncle in your family who's a a alcoholic and shits his pants!!!

Audience : Burst of Laughter

As what we can see in the excerpt above Trevor Noah explains that when you become the attention of society, the media will always try to search for your mistake to be reported. In the excerpt above, Trevor Noah gives an example about media finding that one of your uncles is an alcoholic and he adds new information which is shit his pants. The discourse marker and in the excerpt above connect two different information which is an alcoholic and shits his pants and DM and works as new information indicators. Thus, the marker and between the information of an alcoholic and shits his pants serves as a textual function in terms of marker that indicate new information.

\subsection{Discourse Marker as Sequence Markers}

The third pragmatic function of discourse marker found in the data is discourse marker as sequential markers. When the speaker wanted to convey something that has sequential steps or even the order of an object or other things, the speaker will use markers to relate step one to another step. This marker is called a sequence or relevance marker. The discourse marker which functions as a sequence marker in the data is discourse marker then.

Excerpt 3

Trevor Noah : African Pastor, and-and-This was like it was weird in a good way! He started giving a sermon. And he started talking about Martin Luther King. And then he started talking about sla very.

Audience : Burst of Laughter

Trevor Noah : And I could see, in that moment, there were people in the audience who were like

"God Sa ve TheQueen! God Save The Queen! Somebody STOP this man! God Save The Queen!"

Audience : Burst of laughter

Discourse marker then in excerpt 3 above functions as a sequential marker. It becomes the marker of the action sequence done by the Pastor from he started talking about Martin Luther King into the next action which says he started talking about slavery. Therefore, the discourse marker then in Trevor Noah's stand-up comedy serves a textual function and works as a sequence marker.

\subsection{Discourse MARKer as RePair MARKer}

The next pragmatic function and the last function of the discourse marker's textual function is the repair marker. A repair marker is used when someone aims to repair what he or she has said before. It indicates that the speaker wants to repair the previous discourse and change it with the correct discourse. That is why the marker is called a repair marker.

Discourse markers as repair marker appear frequently in Trevor Noah's stand-up comedy since he speaks continuously and sometimes he unintentionally states something wrong and then he attempts to repair it. We can see the use of discourse marker as repair marker in the excerpt below.

Excerpt 4

Trevor Noah : I'm not gonna front like she has a gangster vibe abouther...

Audience : Burst of Laughter

The appearance of the discourse marker like in the excerpt above indicates self-repair. Trevor at the first time trying to say I am not gonna front and then he corrected his statement by saying she has a gangster vibe. The function of the discourse marker like in the excerpt above fulfills a textual function as a repair marker.

\subsection{Discourse Marker as CoOperation or AgreEMENT MARKER}

The next discourse marker that operates at the interpersonal level is the discourse marker as cooperation or agreement maker. Brinton $(1996,38)$ stated that the interpersonal functions of pragmatic markers are related to Halliday's interpersonal elements (2006, in Spanakaki 2007). A marker with interpersonal function is related to the nature of the social trade and expresses demeanors, sentiments, and assessments. It refers to the writer or speaker's stance towards the content or the potential reader. Therefore, cooperation or agreement maker means that the speaker expresses an idea about something then he or she will try to cooperate or to make an agreement with the audience. There are several 
discourse markers in Trevor Noah's stand-up comedy which serve as cooperation or agreement maker include Alright, yeah and I know. The analysis of the use of discourse marker which functions as Cooperation or Agreement Marker can be seen in the excerpt below.

Excerpt 5

Trevor Noah : If have a black person playing the cello - It's safe to say, that you'vecanceled out the blackness of that event! That's the safest way to introduce blackness into your family. Daddy!! I'm dating a black man!! What?!? He plays the cello! Alright, bring him in, bring him in!

Audience : Burst of Laughter

Discourse marker alright in the excerpt above indicates the agreement of the queen in responding to such a situation. She realizes that she is the queen so that she responded and agreed with the situation above. Therefore, the function of alright in the excerpt above is a response marker and agreement marker.

However, These DMs found and highlighted in the present study also appear in other discourses, such as everyday-conversation, political and media discourse, monologue, etc. For instance, Zarei (2013) describes that discourse markers oh and well are used in the dialog on interchange books which are quite similar to the ones found in this research. Moreover, Castro (2009) also describes that the same discourse markers found in this study also occur in EFL Classroom interaction. To sum up, according to the results of this study, there is no significant difference between discourse markers in humor with the ones used in other variants of discourse.

\section{CONCLUSION}

Most of the DMs found in the present study occur as a response or reaction marker within the speech in stand-up comedy. So, the comic employs impersonation techniques and making a dialogue within the speech; first, the comic says a certain statement and then the comic himself responds to the statement. The discourse markers in stand-up comedy mostly occur in this form. Meanwhile, the rest of the discourse markers appear as topic switchers, new information indicators, sequence or relevance markers, cooperation, and agreement markers, checking understanding markers, and confirmation markers.

Furthermore, those DMs could seemingly help to generate laughter in some ways. First, discourse markers as new information indicators or markers. These discourse markers help to create laughter by providing more information about the discourse. The more information provided, the funnier it will be. Second, discourse markers as response markers that help to generate laughter by using the appropriate response in a particular context. Third, discourse markers as agreement markers can help to generate laughter. For example, saying commonly shared knowledge, then agreeing to it in specific context (functioning like a satire) produce laughter. The last is discourse markers as checking understanding markers. These markers help generate laughter by also having satire in them. So, the comic pretends to ask something very clear in aiming of expressing satire.

Eventually, Discourse markers can help generate laughter if it occurs in the punch line section which is delivered by using stand-up comedy techniques such as impersonation and callback techniques. For instance, the discourse marker and can help to generate laughter in a way that it adds more information so that the stand-up comedy will be funnier because there is a lot of funny information. Besides, discourse marker can also help in generating laughter in terms of the use of particles as mostly response or reaction which is stated repeatedly using callback technique such as the use of discourse marker $Y a$ in Bahasa Indonesia (Yuniar, 2013) and its English equivalent terms found in this research, such as discourse marker huh, yes, ah, and yeah.

\section{REFERENCES}

Aijmer, K. (2002). English Discourse Particles: Evidence from a corpus. Amsterdam: John Benjamins Publishing Company.

Allen, N. J. (1988). Semantics and Madison Avenue: application of the semantic theory of humor to advertising.

Attardo, S. (2008). Semantics and pragmatics of humor. Language and Linguistics Compass, 2(6), 1203 1215.

Attardo, S., \& Raskin, V. (2017). Humor and pragmatics. The Routledge handbook of language and humor, 174-188.

Brinton, L., J. (1996). Pragmatic Markers in English: Grammaticalization and Discourse Functions. Berlin: Walter de Gruyter. 
Brône, G., Feyaerts, K., \& Veale, T. (Eds.). (2015). Cognitive linguistics and humor research (Vol. 26). Walter de Gruyter GmbH \& Co KG.

Castro, C., M., Ch. The Use and Functions of Discourse Markers in EFL Classroom Interaction. Profile Issues in Teachers' Professional Development, accessed 20 March 2021, available from http:www.redalyc.org/articulo.oa?id=169214144005.

Corley, M., \& Stewart, O. W. (2008). Hesitation disfluencies in spontaneous speech: The meaning of um. Language and Linguistics Compass, 2(4), 589-602.

Fraser, B. (1999). What are discourse markers? Journal of Pragmatics, 31: 931-952.

Halliday, M., A., K. \& Hasan, R. (2006). Cohesion in English. Harlow: Pearson Education

Halliday, M., A., K. (1994). An Introduction to Functional Grammar. London: Edward Arnold.

Hyland, K. (ed.) (2013). Discourse Studies Reader. London: Bloomsbury.

Jucker, A. H., \& Ziv, Y. (Eds.). (1998). Discourse markers: Descriptions and theory (Vol. 57). John Benjamins Publishing.

Muller, S. (2005). Discourse Markers in Native and Non-native English Discourse. Amsterdam: John Benjamins Publishing Company.

Norrick, Neal R. (2000). Conversational narrative. Philadelphia: Benjamins.

Piurko, E. (2015). Discourse markers: their function and distribution in the media and legal discourse (Master's thesis).

Rosidi, Sakban. (2008). Research Methodology: A Brief Reminder for the Students of English Department. Malang: The State Islamic University (UIN) of Malang.

Schiffrin, D. (1987). Discourse markers. Cambridge: Cambridge University Press.

Schwarz, J. (2010). Linguistics A spects of Verbal Humor in Stand-Up Comedy. www.researchgate.net

Spanakaki, K. (2007). Translating Humor for Subtitling. Translation Journal. http://www.bokorlang.com/journal/40humor.htm/. Retrieved on March 18, 2019

Yuniar, Dientha. (2013). Ya as Discourse Marker: Indonesian Stand-Up Comedy Strategy in Producing Laughter. International Journal of Applied Linguistics \& English Literature. Vol. 2 No. 6; November 2013

Zarei, F. (2013). Discourse Markers in English, International Research Journal of Applied and Basic Sciences, 4/1: 107-117. 